\title{
PROACTIVITY AT WORK
}

\section{Making Things Happen in Organizations}

Edited by Sharon K. Parker and Uta K. Bindl

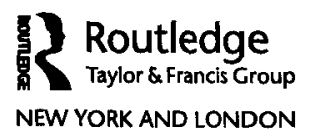




\section{CONTENTS}

Series Foreword

MICHAEL FRESE

Contributors

xiv

\section{INTRODUCTION}

1 Proactivity at Work: A Big Picture Perspective on a Construct that Matters

Sharon K. Parker and Uta K. Bindl

\section{PART I}

Forms of Proactive Behavior

2 Feedback-Seeking Behavior: A Person-Environment Fit Perspective

Katleen De Stobbeleir, Giverny De Boeck, and Nicky Dries

3 Career Proactivity

Sabine Sonnentag

4 A Review of Job-Crafting Research: The Role of Leader Behaviors in Cultivating Successful Job Crafters

Haijiang Wang, Evangelia Demerouti, and Amold B. Bakker 
x Contents

5 Safety Proactivity in the Workplace: The Initiative to Improve Individual, Team, and Organizational Safety 105 Matteo Curcuruto and Mark A. Griffin

6 Issue-Selling: Proactive Efforts toward Organizational Change

Madeline Ong and Susan J. Ashford

7 Foci of Proactive Behavior

Frank D. Belschak and Deanne N. Den Hartog

\section{PART II}

Individual Dynamics of Proactivity

8 Proactive Personality: A Twenty-Year Review

J. Michael Crant, Jia $\mathrm{Hu}$, and Kaifeng Jiang

9 Individual Differences in Proactivity: A Developmental Perspective

Chia-Huei $W u$ and Wen-Dong $L i$

10 Aging and Proactivity

Hannes Zacher and Dorien T.A.M. Kooij

11 Proactive Goals and Their Pursuit

Thomas S. Bateman

12 An Identity-Based Perspective on Proactivity:

Future Work Selves and Beyond

Karoline Strauss and Ciara Kelly

13 The Hot Side of Proactivity: Exploring an Affect-Based Perspective on Proactivity in Organizations

Francesco Cangiano, Uta K. Bindl, and Sharon K. Parker

PART III

Work and Organizational Antecedents and Outcomes of Proactive Behavior

14 Work Design and Proactivity 
15 Leadership and Employee Proactivity

Deanne N. Den Hartog and Frank D. Belschak

16 Proactive Behavior Training: Theory, Design, and Future Directions

Mona Mensmann and Michael Frese

17 Voice Framing and Sensemaking: A Construal-Level Perspective on Proactive Voice Effectiveness

Tina Davidson and Linn Van Dyne

18 The Dark Side of Proactive Behavior: When Being Proactive May Hurt Oneself, Others, or the Organization

Mark C. Bolino, William H. Tumley, and Heather

J. Anderson

19 Teams and Proactivity

T. Brad Harris and Bradley L. Kirkman

\section{CONCLUSION}

20 New Perspectives and Directions for Understanding Proactivity in Organizations

Uta K. Bindl and Sharon K. Parker 